\title{
Ebuhlanti Amandla ngawethu: Womanism and black theology of liberation, in memory of Vuyani Shadrack Vellem
}

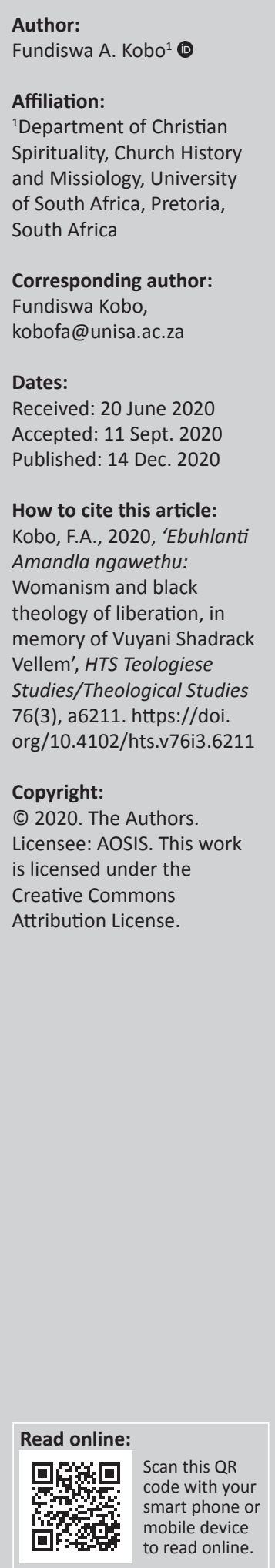

The liberation of black humanity has been an area of scholarly reflection by black theologians and the black consciousness communities. The constructs of oppression such as race, class and sexism amongst others have been critiqued in the quest for liberation of a fragmented black humanity. In this article, this quest for liberation happens within ubuhlanti [kraal], a site for which Vuyani Vellem is 'like a hermeneutical circle, where the mediations of the bonds of spheres and the instantiation of their life take place'. By looking at a fragmented black humanity and black women's experiences, we posit that no western framework could ever be representative of those bodies, ubuhlanti becomes our solution as a heuristic device and symbol of a communication of the efficacy of integrated life. From a womanist perspective, ubuhlanti decentres the West. Ebuhlanti Amandla ngawethu [power belongs to us], as black women and men dialogue issues that affect black humanity. The whole proposition of this dialogue ebuhlanti is animated by our lived experiences, which already offer alternatives for us to decentre.

Contribution: Premised by the lived experiences of black humanity in their quest for liberation, this paper contributes in the dewesternising discourse by presenting alternative epistemologies and spiritualities. A womanist dialogue with black theology of liberation ebuhlanti, a decolonising and decentring praxis for the liberation of black humanity is our solution as blacks.

Keywords: ubuhlanti; amandla ngawethu; the West; decentring; dewesternising; decolonising; black humanity; liberation; black theology; womanism; Vuyani Vellem.

\section{Introduction}

The rupture of broken black bodies and the recycling of these bodies troubled Vuyani Vellem ${ }^{1,2,3}$ throughout his life, scholarship and spirituality. ${ }^{4}$

[T] he subaltern of the world continues unabated with their quest for liberation, no matter how much this quest can be resisted ... even if they continue to be the riff-raff of society, posited. (Vellem 2007:31)

A fragmented black humanity is a problem of the 21st century for black humanity. Starting from Biko's (1987) 'Black person you are on your own' (Maluleke \& Nadar 2004), black consciousness (BC) and black theology of liberation (BTL), Vellem's life-long black assumptions, dubbed black religiosity have long cautioned black people to be authors of their liberation. ${ }^{5}$ They argue that for liberation to be authentic, it must be self-authored. Biko (2012) avers:

We must learn to accept that no group, however benevolent, can ever hand power to the vanquished on a plate. We must accept that the limits of tyrants are prescribed by the endurance of those whom they oppress. As long as we go to Whitey begging cap in hand for our own emancipation, we are giving him further sanction to continue with his racist and oppressive system. (p. 100)

1.I often spend my time amongst ordinary South Africans to listen to the heart of those on the underside of history, hardworking labourers with no labour power, as living work has turned out to be "living" deadly work' (Vellem 2016:64).

2.Ubuhlanti is literally translated as a kraal, to speak of ebuhlanti, one refers to the location in kraal. For the purpose of this article these concepts will be used interchangeably ubuhlanti/kraal, ebuhlanti/in kraal [ebuhlanti means in/inside, at or to the kraal].

3.This article is a reflection of one's journey with Professor Vuyani Vellem, ongoing thoughts that started from the researcher's doctoral studies supervised by Professor Vellem. My doctoral thesis is a dialogue between black theology of liberation and womanist theology for the liberation of a fragmented black humanity. I posit that the response of black theology of liberation to race and class is not the same even though, patriarchal violence is equally a fragmenting evil for a comprehensive liberation of black humanity (Kobo 2018a). It also develops themes of an article on ubuhlanti as life giving space for Africans and amaXhosa in a dialogue of womanists with black also develops themes of an article on ubuhlanti as life giving space for
theologians for the liberation of black humanity. It is also a tribute!

4.Long live the spirit of Vuyani Vellem!

5.The symbolic value of the word 'black' is that it captures the broken existence of black people, summons them collectively to burst the chains of oppression and engage themselves creatively in the instruction of a new society (Thlagale, 1985:126).

Note: Special Collection entitled VukaniBantuTsohangBatho - Spirituality of Black Liberation, sub-edited by Fundiswa Kobo (UNISA) and Rothney Tshaka (UNISA). 
Vellem observed the continuous fragmentation vis-à-vis the growing fascism of the West (2017) and the hardening of the empire (2016) that forces us not only to accept Biko's given propositions, but it forces us to return ebuhlanti as an alternative site that can prioritise the liberation of black humanity. Ebuhlanti we can experience 'an unadulterated paradigm of the liberation heritage, an unapologetic prophetic imagination' (Vellem 2016:64). The bodies of black women are groaning from the dungeons to disturb patriarchal kraals. Ubuhlanti must be rehabilitated from androcentric symbols of black life. The bodies of black women are knowledge to decentre western forms of knowledge and life (Kobo 2019). Spivak (1988) has long posited that these bodies are epistemological disturbances to hegemonic Eurocentric frameworks. As black women and men are equally troubled by a fragmented black humanity, we embark on a journey together to liberate ourselves. Moreover, that journey leads us back ebuhlanti where our quest is realised. Womanism is a comprehensive epistemological agency for black personhood, inspired by a philosophy that celebrates black roots (Ogunyemi 1985), African culture and the ideals of life and faith for black people (Kobo 2018a). 'Black theology of liberation hermeneutics is not about the echoes of Western cannons of knowledge, but the embers of hermeneutics in the zone of non-being' (Vellem 2020:4). 'Womanist theology is black theology' (Wilmore 2004:70). Black theology of liberation and womanist theologies are praxiological and premised by the experiences of oppressed black men and women in a quest to comprehensively liberate a fragmented black humanity. We are in dialogue in kraal because we are black and our liberation is at stake. Ebuhlanti, we are in solidarity, face to face with one another's lived experiences. These experiences disturb Eurocentric forms of knowledge and life and a critique of the West is no longer an alternative.

In this article, the description of ubuhlanti with the view to establish the symbolic value of ubuhlanti amongst Africans with reference to amaXhosa tribe will be given. We look at ubuhlanti as a source of black life and power. The paradox of exclusion and inclusion expressed through the idiom 'umfazi akangeni ebuhlanti emzini' will be looked at as anternal critique of black life ebuhlanti. We look at the paradox presented by ubuhlanti and dialogue is proposed. Ubuhlanti is a decolonising and decentring praxis for the liberation of black humanity. We conclude by looking at Vuyani Vellem's office as a kraal for BTL and womanist theology, as a tribute.

\section{Ubuhlanti}

In the amaXhosa tribe but not exclusively, ubuhlanti (kraal) is a physical space where they keep their livestock that are a source of life and symbolise wealth. Food that nourishes the

6.Disclaimer: as a way of introduction without attempting to be autobiographical I reflect briefly on the experience I share in the processes of the kraal. I was born and bred in the Eastern Cape for the first 5 years of my life I kraal. I was born and bred in the Eastern Cape, for the first 5 years of my life I was nurtured by my maternal grandparents in the rural area in the outskirts of King Williams Town. My umbilical cord was buried there and my rituals are performed there up to this day. that is where my home is, even though my family home is in East London. So every time I travel to the Eastern Cape I must go to my rural home, to the kraal! ebuhlant When I enter I take off my shoes and then an elder will start by reciting our clan names, ooZikhali, ooJojo, ooTiyeka, Butsolo Bentonga, Mbizana ... and present me body such as meat and milk is found ebuhlanti. One common practice worth mentioning in rural homes is how they used to share food, meat, milk and crops during harvest. This sharing and the sanctity that ubuhlanti upholds has been compromised because of scarcity of resources and hunger, which have led to the abandonment of rural homes as people migrated to cities to seek employment and food. In a traditional Xhosa home and in modern homes to some extent, economics are located ebuhlanti and are measured by the number of cattle and livestock in kraal, which signify wealth, good welfare, good harvest and pride. According to Samuelson 'Cattle were the glue of this society and the primary markers of status and wealth' (2007:55). Wealth and education for that matter in such traditional communities found in rural areas is not understood in western forms. Nokuzola Mndende (1998) is amongst African religious practitioners who argues, for instance, that rural women are literate and their knowledge and wisdom must not be measured by western cannons that immediately render these women illiterate (1998). So ubuhlanti represents the subversion of Eurocentric categories of life and epistemologies.

Ubuhlanti is sacred and brings harmony in African homes. It is a meeting of two worlds that make an African: the world of the dead and that of the living for the vitality of an African home (Bujo 1998). Rituals that connect us with our ancestors are performed in kraal. In reverence for our dearly departed, as Xhosas we posit that 'belele nje basathetha', meaning even though our ancestors are asleep they still communicate with us in different modes. Well-articulated also by Ogbu Kalu, 'Those who are dead are never gone: the dead are not dead' (2000:54).

Economics, politics, spirituality and faith of a black home reside ebuhlant $i$; hence, it is sacred as a site for governance and ethics for amaXhosa and Africans (Kobo 2016). Vellem loved ubuhlanti, as a Xhosa man himself, he would speak of 'ubuhlanti booSongo' [the kraal of the Songo clan] with pride. For him ubuhlanti restores every fragmentation that exists in an African household. Ubuhlanti for Vellem is 'the habitus of the living dead who hold all spheres together responsible for the satiation and security of ikhaya' [home] (2007:321). We pray, learn, engage and live ebuhlanti. All things come together.

\section{Ebuhlanti Amandla ngawethu: Black life and power}

Ubuhlanti is a source of black life and power. Vellem's (2007) analysis of Wright Jr. sets the scene for our reflection on black life and power:

According to Wright Jr. (1979:48) black power speaks about nature of humanity. Black power sees the end to which every aspect of human life must be directed as fulfilment. Black people want to fulfil their potential for the larger enrichment of the common life of all mankind. In order to attain personal efficacy, there need to be the presence and the building up of power. Wright Jr. maintains. He makes a pivotal point, namely,

to my ancestors, then I will also start by reciting them 'sicamagushe'. Thank them for good health, protection ... (sometimes with libation) ... Camagu! 
that the Greek words for power (bia) and life (bios) reflect the essential affinity between life and power. Power is basic to life. Without power, there cannot be any life. Institutions transacting ultimate social goals must dare to be power producing repositories. These power-producing repositories are enablers, facilitating human growth toward fulfilment. Hence The Imago Dei in the human being must reflect God's power, His majesty and His might. Our point is that power is life giving. Ubuhlanti thus becomes a communication of the efficacy of bia-a power space for the re-making of life (bios). (pp. 313-314)

We deduce from Vellem's analysis that to speak of black power is to speak about human life. Black power is inherently life-giving and life-affirming. Black humanity's desire is to live and to be free from the shackles of the oppressor. James Cone, the father of BTL has long stated that 'As long as man [/woman] is a slave to another power, he[/she] is not free to serve God with mature responsibility. He [/she] is not free to become what he[/she] is-human' (1969:39) (my own emphasis as a critique of the androcentric language of BTL). Therefore, as Wright Jr. argues black people want to fulfil their potential and carry out their destiny and envisioned self-reality. They are in the quest for a true humanity as articulated by BC. Black consciousness is an expression of group pride, argues Biko, and the determination of the black people to rise and attain the envisaged self (Biko 2012:101).

Vellem's analysis of Wright Jr. exposes the close affinities between power and life and locates ubuhlanti amongst institutions that transact social goals at the centre of human life as life-enhancing power-producing repositories. Ubuhlanti according to Vellem communicates 'efficacy of bia power space for the remaking of life (bios)' (314). Indeed, power, at its core, is life-giving, yet the same power if unchecked can be deadly even in the kraal. Moreover, once one attains the level of normativity against the other, the relationship between power and life is ruptured (Kobo 2016). When there is rupture between power and life, we see a manifestation of violence. An ideally life-affirming $u b u$ hlant $i$ becomes captured and domesticated by patriarchy and androcentric symbols in African culture and heritage. A brief analysis of the Xhosa culture and heritage in the section that follows helps us in our critique and rehabilitation of $u b u$ hlanti for the efficacy of black life.

\section{Umfazi akangeni ebuhlanti ... emzini .....$^{7}$ - Rehabilitating ubuhlanti for our black life}

There is something strange about African languages, in particular isiXhosa language in the sense that one word can have so many connotations and meanings. In the word umfazi, already the contradictions are dealt with because it is translated as woman, but it can also mean a married woman or a young woman. A married woman is the one that is denied access in kraal, but has access in her own home. An unmarried woman has access ebuhlanti.

7.For an in-depth analysis of the phrase or idiom see Kobo 2016.
In that word alone, one is not ultimately able to argue that there is an exclusion without recognising that there is indeed an import of inclusion in it. The heuristic device of ubuhlanti is even worse because it has the praxis of participation in the kraal yet practices of exclusion in certain passages of life. In the rituals of imbeleko, if it is a male child, the meeting about the ritual is held in the kraal by men in his presence. But for females and young children the meeting happens ebuhlanti in their absence (Kobo 2016:4).

In our quest to rehabilitate this site, we observe that the exclusion renders ubuhlanti disintegrated. If others are excluded, this pedagogical site ceases to be credible and powerful. The article by Kobo nuances this cry and calls for rehabilitation of ubuhlanti succinctly. Kobo (2016) asserts:

The article points to irreconcilable contradictions and a dualistic power structure presented and maintained by ubuhlanti, a sanctuary, a sacred space and a symbol of unity, as rituals are performed to connect the living and the departed, lobola negotiations whose aim is to unite families were traditionally held there and umbilical cords are buried in the kraal; if only men are custodians and women prohibited from this site (Gcingca-Ndolo 2008:19; Samuelson 2007:55). The prohibition of women supported by biological reasons that no one has control over but God, i.e. menstruation which renders them unclean to enter this sacred space and there is a claim that menstruation hinders expansion of livestock. Myths of witchcraft cited sometimes to justify this act. What unity can men claim to foster in the absence of women? The article bemoans the dislocation of women from economics and power and concludes that patriarchy can no longer be defended if it upsets life. (p. 4)

So, the point one is making is that ebuhlanti there are intrusions, such as patriarchy, which is one of the Eurocentric impositions that must be dismantled first. It is a rehabilitated kraal that is life-affirming for black people and Africans.

\section{The paradox of ubuhlanti}

As a womanist, who is black and African, ${ }^{8}$ I still remain ebuhlanti! But one that is denuded of patriarchal violence, a rehabilitated ubuhlanti! Outside of ubuhlanti, who will I be?

By problematising the exclusion, the article illuminates the paradox! It will not be accurate to argue that women are excluded. It will not be accurate to argue that women are included. So, the point is that, there is no civilisation or culture devoid of paradox. How we often attempt to deal with paradoxes is exactly the intent of this article, at epistemological, cultural and metaphysical levels.

For example, Christian Faith offers the Cross of Jesus as a tool that can enable us to deal with paradoxes. The cross itself is a symbol of the paradox. It is both ugly and beautiful. The ugliness of the cross points us to the denigration of

$8.1 t$ is important that I state the deeper meaning expressed in the use of punctuations. My womanism is mostly inspired by Chikwenye Ogunyemi, a literary critic from My womanism is mostly inspired by Chikwenye Ogunyemi, a literary critic from Nigeria who coined the term at the same time as Alice Walker from North America. She critiques Walker's definition as an African-American womanism that overlooks African peculiarities. So, she started with the term womanism and modified it to African womanism for it to address the African peculiarities (see Ogunyemi 1985) Black refers to my conviction as one who is a liberation theologian of black theology and a womanist theologian. 
the humanity of the other, the marginalisation of the other, the oppressive systems and their concomitant violent antics (Cone 2011). The cross symbolises humiliation, shame and death yet it symbolises liberation, life and resurrection. One of the important things about the cross is that it is the symbol of defeat yet the symbol of victory!

The point is that paradox is not a unique problem to African culture. This leads directly to the most important theological question about the symbolic use of ubuhlanti in my womanist perspective that we are dealing with paradoxes that make other people think that African culture is not important. For a deeper understanding and reflection on the symbolic value of culture for an African woman, I draw on African women theologians and scholars like, Oduyoye (1986, 1995, 2001), Kanyoro (2001), Lebaka-Ketshabile (1995), Kobo (2016), Masenya (ngwana' Mphahlele) (1998), Phiri and Nadar, (2010:93). They argue that the tensions and paradoxes that are presented by patriarchy must never be equated to the eradication of African culture because indeed womanism does not romanticise culture and certainly does not equate patriarchal violence to the symbolic value of ubuhlanti.

\section{Dialogue}

How do we engage these paradoxical questions? I propose dialogue. The rehabilitation of ubuhlanti suggests that both men and women enter into this dialogue as equal partners. My understanding of dialogue is inspired by Enrique Dussel's definition of dialogue as something that creates an opportunity for philosophies from the peripheries to be recognised (2009). The absence of dialogue is the characteristic feature of patriarchal violence and it is a conquering form of spirit and rationality that womanists find problematic. Womanism is about dialogue.

The infiltration of ubuhlanti by Eurocentric categories especially sexist, patriarchal and racist rationality, a point we will return to later and how they impact on the self-understanding of humanity amongst black people is the issue that is symbolised by the paradoxes that I am talking about. It is demonstrated in what I call pseudo-spirituality ${ }^{9}$ therefore $\ldots$ an understanding of spirituality that occludes discovery and conquest. Because it is the very spirit of conquest and the inability to dialogue that led to the denigration of African culture by missionaries in the first place (see Biko 2012; Kalu 2005; Maluleke 1995; Oduyoye 1986; Vellem 2016). Biko (2012) poignantly puts it as follows:

It was the missionaries who confused the people with their new religion. They scared our people with stories of hell. They painted their God as a demanding God who wanted worship or else. People had to discard their clothes and their customs in order to be accepted in this new religion. Knowing how religious the African people were, the missionaries stepped up their terror campaign on the emotions of the people with their detailed accounts of eternal burning, tearing of hair and gnashing of teeth ... This cold and cruel religion was strange to the indigenous people ... with the ultimate acceptance of the western religion down went our cultural values. (p. 103)

It is a Eurocentric understanding and interpretation of Christianity that suggests that our Africanness, our interconnectedness, is barbaric. Cone has long posited that it is not a sin to be black and African and throughout his life and theology until his death he has tried to teach black people to love themselves and not to apologise for being black and Christian, and African and Christian. Dialogue enhances this co-existence.

\section{Ubuhlanti: A decolonising and decentring praxis $^{10}$}

In the context of decoloniality, ubuhlanti that is denuded of patriarchal violence suggests the use of this heuristic device, firstly, as an affirmation of what a womanist like myself is as distinct from a feminist should be viewed as a symbol that points beyond patriarchy, rather than one that is domesticated by patriarchy. Secondly, its application in relation to fraudulent external impositions that undermine and destroy the cultural dispensation and the integrity of life of black African people and women in particular presents it as a symbol of protest, especially faith in protest. The existence of this paradox ebuhlanti should be viewed as such, the protest of a woman who is allowed in favour of the one who is excluded and debunking of patriarchy by the one who is in solidarity with the one who is excluded. It's a paradox of protest! It is a symbol that undeniably exposes paradox as protest rather than paradox as a norm, because it points beyond ... ubuhlanti it is a shrine of life for African people!

That is why ubuhlanti decentres the West, it puts African life at the centre that only the West occupied. It exposes the shift in the centre that is also happening in the globe. So, in a womanist dialogue with BTL ebuhlanti, the primary issue is not to rearticulate, regurgitate the deeper sentiments that were expressed by Cone $(1969,1984,2011)$, Vellem (2015, 2016, 2017), and others, Cannon (1984, 2006, 2014), Oduyoye $(1986,1995,2001)$ and others. The primary concern that is a methodological question today is the cracks that are now there for everyone to see that affirm that we decentre the West and remain ebuhlanti. 'In unthinking the West, our position is that Western civilisation can be overcome; it is crumbling as we speak. The poor and the marginalised, not Western civilisation, constitute our future for the development of life-affirming alternatives of civilisation and knowledge', posits Vellem (2017:2; 2019a).

A global sign one sees is the shift in the European politics for instance, the major conventional parties not making it into the European Union (EU) parliament. Most of the parties that 10.Ebuhlanti the thesis is that we are dewesternising, decentring, delinking and unthinking the West. 
won are Right fundamentalist nationalistic political parties. ${ }^{11}$ The obstinacy of racism in the West has resulted in cracks. Dewesternisation is happening. ${ }^{12}$ The choice to make is whether one will be swallowed by the tremors and rubble that will come out of these cracks or rather find alternatives in the quest for one's liberation. Moreover, our alternative is the kraal.

Ebuhlanti we are inspired by a need to rally together as black people around the causes of our oppression, which for Biko is the blackness of our skin (2012:101). He saw this many years ago that:

$[W]$ e are oppressed not as individuals, not as Zulus, Xhosas, Vendas or Indians. We are oppressed because we are black. ${ }^{13} \mathrm{We}$ must use that very concept to unite ourselves and to respond as a cohesive group. We must cling to each other with a tenacity that will shock the perpetrators of evil. (2012:108)

So, we are in dialogue to fix the degradations and fragments in our humanity and we posit that no external vision of liberation for black people is allowed in the kraal.

Vellem observes that the empire is not getting any better but rather is hardening like a husk (2016) and the fascism of the West is growing (2017). Brexit for instance is an expression of how the West is determined never to address the things they caused themselves. They are the ones who brought black people to work by ship in Britain as beneficiaries of slavery and all of a sudden, they are unable to contend with the fact these people are growing in numbers. An observation by Vuyani Vellem ${ }^{14}$ to further express this is that what you see in Britain, the Netherlands, United States of America amongst the beneficiaries of slavery today would have never been there had Africa not been there. So, one wonders where that leaves us as black people? Ebuhlanti, BTL and womanists have moved away from knowledge systems, spiritualities and bodies as enunciated and intimated through the commodification of life. Our life is in the kraal.

\section{Professor Vuyani Vellem's office as a kraal, ubuhlanti, of black theology of liberation: A tribute!}

Vuyani Vellem (2017) introduced himself always as a student of BTL.

11.viewed 19 June 2020 , from https://www.economist.com/charlemagnes notebook/2019/05/26/populists-fall-short-of-expectations-in-the-europeanelections.

12.See Walter Mignolo who argues that 'Today, one feels that, with the collapse (financial, political and ethical) of the European Union and the critical moment currently taking place in the United States both domestically and internationally, we are living a change of epoch, not an epoch of change. Things are shifting: centres are moveable; sensibilities are shifting the illusion of the end of history after 500 years of localised Western history, consolidation and domination is ending. Older - much older - histories of civilisations are re-emerging. Globalism (the neoliberal vision of homogenising the planet) is spinning out of control and every western universal is under siege' (Mignolo 2013:2).

13.For more insights into the links between blackness and oppression and fragmentation of blacks, see Thlagale 1985, Vellem 2007.

14.This paragraph is in fact a reflection on the conversation that I had with the late Professor Vuyani Vellem about Brexit as an example of the cracks that are evident in the West that are there, on the 28 May 2019
He avers:

I am a black male and have been a student of Black Theology of Liberation (BTL) because my days at the Federal Theological Seminary (Fedsem) in the late 1980s. One of the most important things that made this school so attractive to me is its inextricable link with black consciousness (BC), a philosophy that truly inspires my reason of faith as a black person. (p. 1)

He was black! His theology was black! He was located ebuhlanti!

He critiqued constructs of oppression that converged on top of black bodies. He critiqued evil and destructive theologies and epistemologies that killed the mind and spirit of our people. In one of his works, Vellem (2014:3) poignantly calls us into remembering links between Western Christianity and cultural subjugation of black Africans. Moreover, he was aware that for as long as one does that, he or she will be killed not only by the empire but also by his or her own fellow black people.

So, his office was for his students in kraal, a liberative space for oppressed black minds and spirits. Ubuhlanti benkululeko yomntana omnyama, the kraal for the freedom of black children. It was a space for hope and life. The ritual was almost a routine upon entering the office, the kraal, he shifted from his desk to the visitors' space conveniently located in front of the white board that he used to teach his students about liberation and black theology. Moreover, many who entered that kraal have never been the same again. Sivukile! Retsohile! We are awake!

Whilst he is not here physically ebuhlanti, our black prophet is not dead, but has joined a cloud of witness and has become our ancestor. He has now gone to rest with our ancestors, Steve Biko, Tiyo Soga, James Cone, 'Elele nje usathetha', Camagu Msimang, Songo, Nonkosi, NoThabizolo!

Whilst his scholarly contributions will certainly continue to speak for him for many years to come, his ideas and dream that every black child be educated will certainly be realised through VukaniBantuTsohangBatho, a historical project of black liberation whose vision is to invest in spirituality for liberation, a movement that he founded. Long live the spirit of Vuyani Vellem! Amandla ngawethu!

\section{Conclusion}

A reflection on one's journey with Professor Vuyani Vellem and his work brings me to a conclusion that he did not deny paradox, as a custodian of ubuhlanti, he did not romanticise culture, his was a journey to deal with paradoxes and dent them for the affirmation of life. Amandla ngawethu, as he affirmed black power as life in the kraal.

So, the lesson is that anyone who denies the existence of paradoxes in her or his culture or field, the academic interest 
must just accept that paradoxes for her or him are kraals of conquest and the killing of life.

\section{Acknowledgements Competing interests}

The author declares that she has no financial or personal relationship(s), which may have inappropriately influenced her in writing this article.

\section{Author's contributions}

I declare that I am the sole author of this research article.

\section{Ethical consideration}

The author confirms that ethical clearance was not needed for the study.

\section{Funding information}

This research received no specific grant from any funding agency in the public, commercial or not-for-profit sectors.

\section{Data availability statement}

Data sharing is not applicable to this article as no new data were created or analysed in this study.

\section{Disclaimer}

The views and opinions expressed in this article are those of the author and do not necessarily reflect the official policy or position of any affiliated agency of the author.

\section{References}

Biko, S., 1987, I write what I like, Heinemann, Oxford.

Biko, S., 2012, 'We blacks', in A. Stubbs (ed.), I write what I like, pp. 29-35, Picador Africa, Johannesburg.

Bujo, B., 1998, The ethical dimension of community: The African model and the dialogue between the North and South, Paulines Publications Africa, Nairobi.

Cannon, K.G., 1984, 'Moral wisdom in the black women's literary tradition', Annual of the Society of Christian Ethics 4, 171-192. https://doi.org/10.5840/asce 1984410

Cannon, K.G., 2006, 'Response. To the roundtable discussion: Must I be womanist?', Journal of Feminist Studies in Religion (Indiana University Press) 22(1), 96-98. https://doi.org/10.2979/FSR.2006.22.1.96

Cannon, K.G., 2014, 'Lessons of liberation in the struggle for freedom', in V. Vellem, P. Dibeela \& P. Lenka-Bula (eds.), Prophet from the South: Essays in honour of Allan Aubrey Boesak, pp. 171-184, Sun Press, Stellenbosch.

Cone, J.H., 1969, Black theology \& black power, Harper, San Francisco, CA.

Cone, J.H., 1984, For my people. Black theology and the black church, Orbis Books, Maryknoll, New York, NY.

Cone, J.H., 2011, The cross and the lynching tree, Orbis Books, Maryknoll, New York, NY.
Dussel, E., 2009, 'A new age in the history of philosophy. The world dialogue between philosophical traditions', Philosophy \& Social Criticism 35(5), 499-516. https://doi. philosophical traditions', Philosophy
org/10.1177/0191453709103424

Gcingca-Ndolo, Z.C., 2008, 'Amasiko nezithethe neendlela zokuziphatha kwaXhosa', Unpublished Master's thesis, University of South Africa, Pretoria.

Kalu, O.U., 2000, 'Ancestral spirituality and society in Africa', in J.K. Olupona (ed.), African spirituality: Forms, meanings and expressions, pp. 54-84, The Crossroad Publishing Company, New York, NY.

Kanyoro, M., 2001, 'Engendered communal theology: African women's contribution to theology in the twenty-first century', Feminist Theology 9(27), 36-56. https:// doi.org/10.1177/096673500100002704

Kobo, F.A., 2016, 'Umfazi akangeni ebuhlanti emzini ... A womanist dialogue with black theology of liberation in the 21st century', HTS Teologiese Studies/ Theological Studies 72(1), a3268. https://doi.org/10.4102/hts.v72i1.3268

Kobo, F.A., 2018a, 'A womanist dialogue with black theology of liberation in the twenty first century', Unpublished PhD thesis, University of Pretoria, Pretoria.

Kobo, F.A., 2018b, 'A womanist exposition of pseudo-spirituality and the cry of an oppressed African woman', HTS Teologiese Studies/Theological Studies 74(1), 4896. https://doi.org/10.4102/hts.v74i1.4896

Kobo, F.A., 2019, “'Womanism and black anthropology”: In memory of James Cone', Journal of Theology for Southern Africa 162 \& 163, 82-100.

Lebaka-Ketshabile, L., 1995, 'Reconstructing theology: A woman's perspective', Journal of Black Theology in South Africa 9(2), 43-51.

Maluleke, T.S., 1995, 'Black theology lives! On a permanent crisis', Journal of Black Theology in South Africa 9(1), 1-30.

Maluleke, T.S. \& Nadar, S., 2004, 'Alien fraudsters in the white academy: Agency in gendered colour', Journal of Theology for Southern Africa 120, 5-17.

Mignolo, W.D., 2013, Re-emerging, decentring and delinking. Shifting the geographies of sensing, believing and knowing, Platform 005: Ibraaz, viewed 17 May 2018 , from https://www.ibraaz.org/essays/59.

Mndende, N., 1998, 'Womanist theology: A problem of definition', paper presented at the First African Womanist Workshop, University of Cape Town, Cape Town.

Oduyoye, M.A., 1986, Hearing and knowing. Theological reflections on Christianity in Africa, Orbis Books, Maryknoll, New York, NY.

Oduyoye, M.A., 1995, Daughters of Anowa: African women and patriarchy, Orbis Books, Maryknoll, New York, NY.

Oduyoye, M.A., 2001, Introducing women's theology, Sheffield Academic Press.

Ogunyemi, C.O., 1985, 'Womanism: The dynamics of the contemporary black female novel in English', Signs 11(1), 63-80. https://doi.org/10.1086/494200

Phiri, I. \& Nadar, S., 2010, 'African women's theologies', in D.B. Stinton (ed.), African theology on the way, pp. 90-100, Society for Promoting Knowledge, London.

Samuelson, M., 2007, Remembering the nation, Dismembering women? Stories of the South African transition, UKZN Press, Scottsville, KY

Thagale, B., 1985, 'Towards a black theology of labour', in C. Villa-Vicencio \& J. De Gruchy (eds.), Resistance and hope: South African essays in honour of Beyers Naude, pp. 126-134, Eerdmans, Grand Rapids, MI.

Vellem, V.S., 2007, 'The symbol of liberation in South African public life: A black theological perspective', Unpublished PhD thesis, University of Pretoria, Pretoria.

Vellem, V.S., 2012, 'Interlocution and black theology of liberation in the 21st century: A Reflection', Studia Historiae Ecclesiasticae 38(Suppl. 1), 1-9.

Vellem, V.S., 2014, 'Spirituality of liberation: A conversation with African religiosity', HTS Teologiese Studies/Theological Studies 70(1), 7. https://doi.org/10.4102/hts. v70i1.2752

Vellem V.S., 2015, 'Unshackling the church', HTS Teologiese Studies/Theological Studies 71(3), Art. \#3119, 5 pages. https://doi.org/10.4102/hts.v71i3.3119

Vellem, V.S., 2016, 'A hardening husk of neoliberal antics: Worrying signs of the times', in Oikotree Movement (ed.), Life-enhancing learning together, pp. 60-77, (Samjeong, Korea), Less Press \& Life in Beauty Press.

Vellem, V.S., 2017, 'Un-thinking the West: The spirit of doing black theology of liberation in decolonial times', HTS Teologiese Studies/Theological Studies 73(3), 1-9. https://doi.org/10.4102/hts.v73i3.4737

Vellem, V.S., 2019a, 'Cracking the eurocentric code. A battle on the banks of the "new blood rivers"', Missionalia 46(2), 2019, 267-287. https://doi.org/10.7832/46-2-313

Vellem, V.S., 2020, 'Hermeneutical embers from the "zone of non-being"', in J. Havea (ed.), Mission and context, Lexington Books, Lanham.

Wilmore, G.A., 2004, Pragmatic spirituality: The Christian faith through an Africentric lens, New York University Press, New York, NY.

Wright, N. Jnr., 1979, 'Black power: A religious opportunity', in Cone \& Wilmore Black Theology, A documentary History, 1966-1979, Orbis, New York, 48-61. 